haemagglutinin (HA) and six-histidine tags. pST1420 contained the mutant cut14 gene.

Overproduction and protein purification. For overproduction of Cut 3 and Cut14 proteins, cells carrying the plasmids described above were cultured in minimal EMM2 in the absence of thiamine for $14 \mathrm{~h}$ at $33^{\circ} \mathrm{C}$ (for overproducing the mutant Cut 14 protein, for $23 \mathrm{~h}$ at $26^{\circ} \mathrm{C}$ ). Whole-cell extracts were prepared for $1-2 \times 10^{10}$ cells. Subsequent manipulations were done at $0-4{ }^{\circ} \mathrm{C}$. Cells were washed once in $\mathrm{XB}$ extraction buffer $(40 \mathrm{mM}$ Tris- $\mathrm{HCl}, \mathrm{pH} 8.0$, containing $0.5 \mathrm{M} \mathrm{NaCl}, 10 \%$ glycerol and $1 \mathrm{mM}$ PMSF), disrupted by glass beads in $10 \mathrm{ml}$ XB buffer, and centrifuged at 40,000 r.p.m. for $1 \mathrm{~h}$ using a Beckman $50.2 \mathrm{Ti}$ rotor. The supernatant was bound batchwise to $1 \mathrm{ml}$ of Ni-NTA agarose (Qiagen) ${ }^{16}$ for $2 \mathrm{~h}$. The resin was washed sequentially with $10 \mathrm{ml} \mathrm{XB}$ containing $20 \mathrm{mM}$ imidazole, then $10 \mathrm{ml}$ buffer $\mathrm{N}(20 \mathrm{mM}$ Tris- $\mathrm{HCl}$, pH 7.5, containing $150 \mathrm{mM} \mathrm{NaCl}, 10 \%$ glycerol, $0.02 \% \mathrm{NP}-40$ and $0.1 \mathrm{mM}$ PMSF) containing $20 \mathrm{mM}$ imidazole, and poured onto a column. After the resin was washed with $5 \mathrm{ml}$ buffer $\mathrm{N}$ containing $20 \mathrm{mM}$ imidazole, bound proteins were eluted sequentially with $5 \mathrm{ml}$ buffer $\mathrm{N}$ containing $200 \mathrm{mM}$ imidazole and then $5 \mathrm{ml}$ buffer $\mathrm{N}$ containing $1 \mathrm{M}$ imidazole. Fractions containing Cut3 and/or Cut14 were eluted by the addition of $200 \mathrm{mM}$ imidazole and stored at $-80^{\circ} \mathrm{C}$. Cut3 was partly cleaved during isolation procedures, but if the procedures were rapidly done in a small-scale preparation, the complex containing non-cleaved Cut 3 could be obtained. This preparation also had the renaturation activity. The cellular content of Cut 3 in non-overproducing wild type was determined to be $3 \times 10^{3}$ molecules per cell using recombinant Cut 3 as standard for immunoblot, equivalent to one molecule per $8 \mathrm{~kb}$ genomic DNA.

DNA reannealing assay. Procedures similar to those described ${ }^{18}$ were used. Complementary DNA strands were obtained by heat-denaturing $3 \mathrm{~kb}$ long EcoRV-linearized pBluescript KS(+). Reaction mixtures (final volume $20 \mu \mathrm{l}$ ) contained the buffer A (20 mM Tris-HCl, pH 7.5, containing $10 \%$ glycerol, $50 \mathrm{mM} \mathrm{NaCl}, 10 \mathrm{mM} \mathrm{MgCl}_{2}, 1 \mathrm{mM}$ ATP, $1 \mathrm{mM}$ DTT), $12 \mu \mathrm{M}$ (as nucleotides) heat-denatured DNA and the protein fractions (the Cut3-Cut14 complex, 30$60 \mathrm{nM}$; RecA, $400 \mathrm{nM})$. For ATP-free reactions, buffer B $(20 \mathrm{mM}$ Tris- $\mathrm{HCl}$ at $\mathrm{pH} 7.5$, containing $10 \%$ glycerol, $100 \mathrm{mM} \mathrm{NaCl}, 1 \mathrm{mM} \mathrm{DTT}$ ) was used instead of buffer A. Reaction mixtures were incubated at $30^{\circ} \mathrm{C}$ for various lengths of time. The reaction was terminated by adding $2 \mu \mathrm{l}$ of $8 \%$ SDS and $100 \mathrm{mM}$ EDTA. Samples were analysed on $0.7 \%$ agarose gel at $1.4 \mathrm{~V} \mathrm{~cm}^{-1}$ for $16 \mathrm{~h}$, and DNA was visualized by ethidium bromide staining.

Sucrose density-gradient centrifugation. A linear sucrose gradient $(5.0 \mathrm{ml}$, $10-40 \%$ ) made in HB buffer ${ }^{17}$ was overlaid with $0.1 \mathrm{ml} \mathrm{Cut3-Cut14}$ complex solution $\left(4.5 \mu \mathrm{g} \mathrm{ml}^{-1}\right)$ or cell extracts (equivalent to $4 \times 10^{8}$ cells) and run at 40,000 r.p.m. for $16 \mathrm{~h}$ at $4{ }^{\circ} \mathrm{C}$. We analysed 20 fractions by immunoblot using antibodies against Cut 3 or Cut14HA.

Identification of mutation sites. Approximate location of the mutation sites was determined by integration rescue. Genomic DNAs were isolated from the corresponding regions of the temperature-sensitive mutant genome, followed by nucleotide sequence determination.

Preparation of nuclear chromatin and S1 nuclease digestion. The procedures previously described for nuclear chromatin ${ }^{20}$ were followed. As added $530 \mathrm{U}$ of $\mathrm{S} 1$ or $100 \mathrm{U}$ of mung-bean nuclease (TaKaRa) to $70 \mu \mathrm{l}$ chromatin of $S$. pombe cells, incubated at $36^{\circ} \mathrm{C}$ for $30 \mathrm{~min}$. The reaction was terminated by $50 \mathrm{mM}$ EDTA. DNAs were extracted after SDS lysis.

Received 6 June; accepted 17 July 1997.

1. Holm, C. Coming undone: how to untangle a chromosome. Cell 77, 955-957 (1994).

2. Swedlow, J. R., Agard, D. A. \& Sedat, J. W. Chromosome structure inside the nucleus. Curr. Opin. Cell Biol. 5, 412-416 (1993)

3. Hirano, T., Mitchison, T. J. \& Swedlow, J. R. The SMC family: from chromosome condensation to dosage compensation. Curr. Opin. Cell Biol. 7, 329-336 (1995).

4. Gasser, S. M. Coiling up chromosomes. Curr. Biol. 5, 357-360 (1995).

5. Koshland, D. \& Strunnikov, A. Mitotic chromosome condensation. Annu. Rev. Cell Dev. Biol. 12, 305333 (1996).

6. Boy de la Tour, E. \& Laemmli, U. K. The metaphase scaffold is helically folded: sister chromatids have predominantly opposite helical handedness. Cell 55, 937-944 (1988).

7. Belmont, A. S., Sedat, J. W. \& Agard, D. A. A three dimensional approach to mitotic chromosome structure: evidence for a complex hierarchical organization. J. Cell Biol. 105, 77-92 (1987).

8. Strunnikov, A. V., Larionov, V. L. \& Koshland, D. SMCl: an essential yeast gene encoding a putative head-rod-tail protein is required for nuclear division and defines a new ubiquitous family. J. Cell Biol. 123, 1635-1648 (1993).

9. Saka, Y. et al. Fission yeast cut 3 and cut 14 , members of a ubiquitous protein family, are required for chromosome condensation and segregation in mitosis. EMBO J. 13, 4938-4952 (1994).

10. Hirano, T. \& Mitchison, T. J. A heteromeric coiled-coil protein required for mitotic chromosome condensation in vitro. Cell 79, 449-458 (1994).

11. Saitoh, N., Goldberg, I. G., Wood, E. R. \& Earnshaw, W. C. ScII: an abundant chromosome scaffold protein is a member of a family of putative ATPase with an unusual predicted tertiary structure. J. Cell Biol. 127, 303-318 (1994)

12. Chuang, P.-T., Albertson, D. G. \& Meyer, B. J. DPY-27: a chromosome condensation protein homolog that regulates $C$. elegans dosage compensation through association with the $\mathrm{X}$ chromosome. Cell 79, 459-474 (1994).

13. Strunnikov, A. V., Hogan, E. \& Koshland, D. SMC2, a Saccharomyces cerevisiae gene essential for chromosome segregation and condensation defines a subgroup within the SMC-family. Genes Dev. 9, 587-599 (1995).

14. Bryant, F. R. \& Lehman, I. R. On the mechanism of renaturation of complementary DNA strands by the recA protein of Escherichia coli. Proc. Natl Acad. Sci. USA 82, 297-301 (1985).

15. Maundrell, K. nmt1 of fission yeast. J. Biol. Chem. 265, 10857-10864 (1990).

16. Côté, J., Quinn, J., Workman, J. L. \& Peterson, C. L. Stimulation of GAL4 derivative binding to nucleosomal DNA by the yeast SW1/SNF complex. Science 265, 53-60 (1994).

17. Funabiki, H. et al. Cut2 proteolysis required for sister-chromatid separation in fission yeast. Nature 381, 438-441 (1996).

18. Bryant, F. R., Menge, K. L. \& Nguyen, T. T. Kinetic modeling of the RecA protein promoted renaturation of complementary DNA strands. Biochemistry 28, 1062-1069 (1989).

19. Jessberger, R., Riwar, B., Baechtold, H. \& Akhmedov, A. T. SMC proteins constitute two subunits of the mammalian recombination complex RC-1. EMBO J. 15, 4061-4068 (1996).

20. Chikashige, Y. et al. Composite motifs and repeat symmetry in S. pombe centromeres: direct analysis by integration of NotI restriction sites. Cell 57, 739-751 (1989).

21. Hirano, T., Kobayashi, R. \& Hirano, M. Condensins, chromosome condensation protein complexes containing XCAP-C, XCAP-E and a Xenopus homolog of the Drosophila Barren protein. Cell 89, 511521 (1997).

22. Connelly, J. C. \& Leach, D. R. F. The $s b c C$ and $s b c D$ genes of Escherichia coli encode a nuclease involved in palindrome inviability and genetic recombination. Genes Cells 1, 285-291 (1996).

23. Bhat, M. A., Philp, A. V., Glover, D. M. \& Bellen, H. Chromatid segregation at anaphase requires the barren product, a novel chromosome-associated protein that interacts with topoisomerase II. Cell 87, $1103-1114$ (1996)

Acknowledgements. We thank T. Horii, H. Ogawa and Y. Adachi for help and advice; T. Hirano for data before publication; and T. Hyman for critically reading the manuscript. This work was supported by grants from the Ministry of Education, Science and Culture of Japan, the Japan Science Technology Foundation (CREST), and the Human Frontier Science Promotion Organization. T.S. is the recipient of a Japan Science Promotion Society fellowship.

Correspondence and requests for materials should be addressed to M.Y. (e-mail: yanagida@kozo.biophys. kyoto-u.ac.jp).

\section{Metal ion catalysis during splicing of premessenger RNA}

\section{Erik J. Sontheimer, Sengen Sun \& Joseph A. Piccirilli}

Howard Hughes Medical Institute, Department of Biochemistry and Molecular Biology, and Department of Chemistry, The University of Chicago, 5841 South Maryland Avenue, MC1028, Chicago, Illinois 60637, USA

The removal of intervening sequences from premessenger RNA is essential for the expression of most eukaryotic genes. The spliceosome ribonucleoprotein complex catalyses intron removal by two sequential phosphotransesterification reactions ${ }^{1}$, but the catalytic mechanisms are unknown. It has been proposed that two divalent metal ions may mediate catalysis of both reaction steps, activating the $2^{\prime}$ - or 3 '-hydroxyl groups for nucleophilic attack and stabilizing the $3^{\prime}$-oxyanion leaving groups by direct coordination ${ }^{2}$. Here we show that in splicing reactions with a precursor RNA containing a $3^{\prime}$-sulphur substitution at the $5^{\prime}$ splice site, interaction between metal ion and leaving group is essential for catalysis of the first reaction step. This establishes that the spliceosome is a metalloenzyme and demonstrates a direct parallel with the catalytic strategy used by the self-splicing group I intron from Tetrahymena. In contrast, $3^{\prime}$-sulphur substitution at the $3^{\prime}$ splice site provides no evidence for a metal ion-leaving group interaction in the second reaction step, suggesting that the two steps of splicing proceed by different catalytic mechanisms and therefore in distinct active sites.

Substitution of an oxygen leaving group by sulphur ${ }^{4}$ provides a means to test metal ion-leaving group interactions because various metals differ in their ability to coordinate sulphur: for example, $\mathrm{Mn}^{2+}$ readily accepts sulphur as a ligand, whereas $\mathrm{Mg}^{2+}$ does not ${ }^{5-8}$. Thus, a switch in metal specificity from $\mathrm{Mg}^{2+}$ to $\mathrm{Mn}^{2+}$ following 
sulphur substitution is evidence for a direct metal ion-leaving group interaction ${ }^{3}$.

We used enzymatic ligation ${ }^{9}$ to synthesize an adenovirus-derived splicing substrate (Ad5-1S) containing a single 2 '-deoxy- 3 '-thiouridine at the $5^{\prime}$ splice site (Fig. 1a), in which sulphur replaces the $3^{\prime}$-oxygen leaving group in the first step of splicing. We also prepared the standard transcribed adenovirus substrate ${ }^{10}$, as well as ligated control substrates containing a single $2^{\prime}$-deoxyuridine (Ad5-1D) or unmodified uridine (Ad5-1R) at the 5' splice site. The absence of a $2^{\prime}$-hydroxyl group at the $5^{\prime}$ splice site is known to have no effect on the rate or accuracy of pre-mRNA splicing ${ }^{9}$. All four substrates were tested for in vitro splicing in EDTA-pretreated HeLa nuclear extract (Fig. 2a). The control adeno transcript and the ligated substrates Ad5-1R and Ad5-1D all behaved similarly: no splicing occurred in the absence of exogenous divalent metal ions (Fig. 2a, lanes 2, 6 and 10), and efficient splicing occurred in the presence of $1.5 \mathrm{mM} \mathrm{MgCl}_{2}$ (Fig. 2a, lanes 3, 7 and 11) or $1.5 \mathrm{mM}$ $\mathrm{MnCl}_{2}$ (Fig. 2a, lanes 4, 8 and 12). The Ad5-1S substrate also failed to undergo splicing in the absence of exogenous divalent metal ions (Fig. 2a, lane 14); however, in contrast to the control substrates, $1.5 \mathrm{mM} \mathrm{MgCl}_{2}$ was unable to support splicing (Fig. 2a, lane 15). This inhibition of splicing in $\mathrm{MgCl}_{2}$ was apparent at all times up to 2 hours, and at $\mathrm{MgCl}_{2}$ concentrations up to $3.5 \mathrm{mM}$ (data not shown). When the splicing buffer contained $1.5 \mathrm{mM} \mathrm{MnCl}_{2}, 5^{\prime}$-splice-site cleavage and lariat formation occurred efficiently (Fig. 2a, lane 16), but the second step of the reaction did not. Poor nucleophilicity of sulphur at phosphate centres ${ }^{11}$, which has been observed in both non-enzymatic ${ }^{12}$ and enzymatic ${ }^{13}$ reactions, may be the reason for inhibition of the second step of splicing. The appearance of splicing intermediates depended on added nuclear extract (Fig. 2a, lane 17) and therefore did not simply result from incubation of the $3^{\prime}$-thiomodified substrate under these buffer conditions. A $2^{\prime}$-O-methyl oligonucleotide that sequesters the $5^{\prime}$ end of U1 small nuclear (sn) RNA $^{14}$ blocked the reaction, but a nonspecific oligonucleotide did not, indicating that the spliceosome was responsible for $5^{\prime}$-splicesite cleavage of the modified substrate (data not shown).

To demonstrate the accuracy of the Ad5-1S splicing reaction in $\mathrm{MnCl}_{2}$, we synthesized a fragment of Ad5-1S pre-mRNA with a single radiolabelled phosphate adjacent to the $2^{\prime}$-deoxy- 3 '-thiouridine residue (Fig. 2b, top). The sulphur-phosphorus bond of a
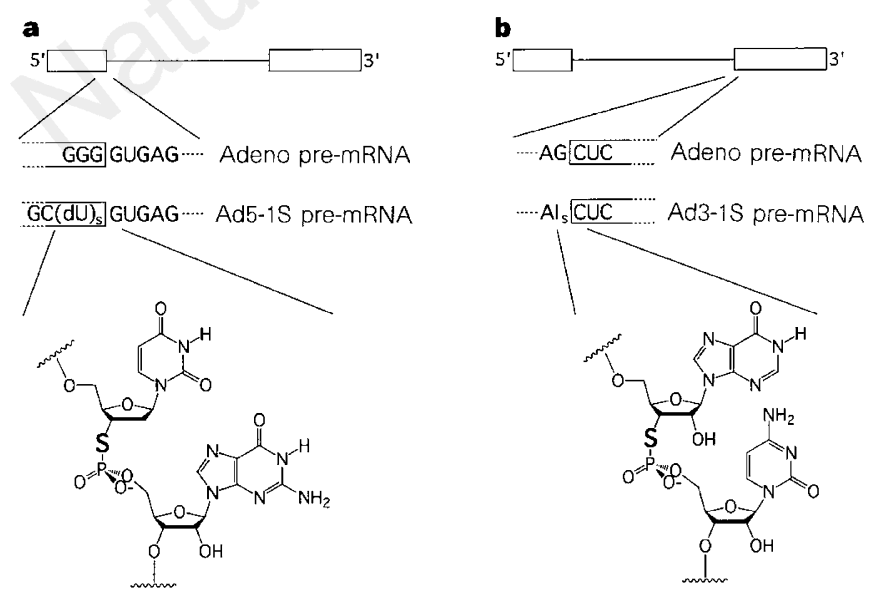

Figure 1 Modified adenovirus pre-mRNA substrates for in vitro splicing. The premRNAs are shown schematically at the top, with splice-site sequences underneath. The structures of the nucleosides flanking the 3 '-S-phosphorothiolate bond are shown at the bottom. $\mathbf{a}$, In the Ad5-1S substrate, the guanosine at $5^{\prime}$ splice-site position-1 was changed to $2^{\prime}$-deoxy-3'-thiouridine, and the guanosine at position-2 to cytidine to avoid formation of a cryptic $5^{\prime}$ splice site ${ }^{25} \cdot \mathbf{b}$, In the Ad3$1 \mathrm{~S}$ substrate, the guanosine at $3^{\prime}$-splice-site position-1 was changed to $3^{\prime}$ thioinosine.

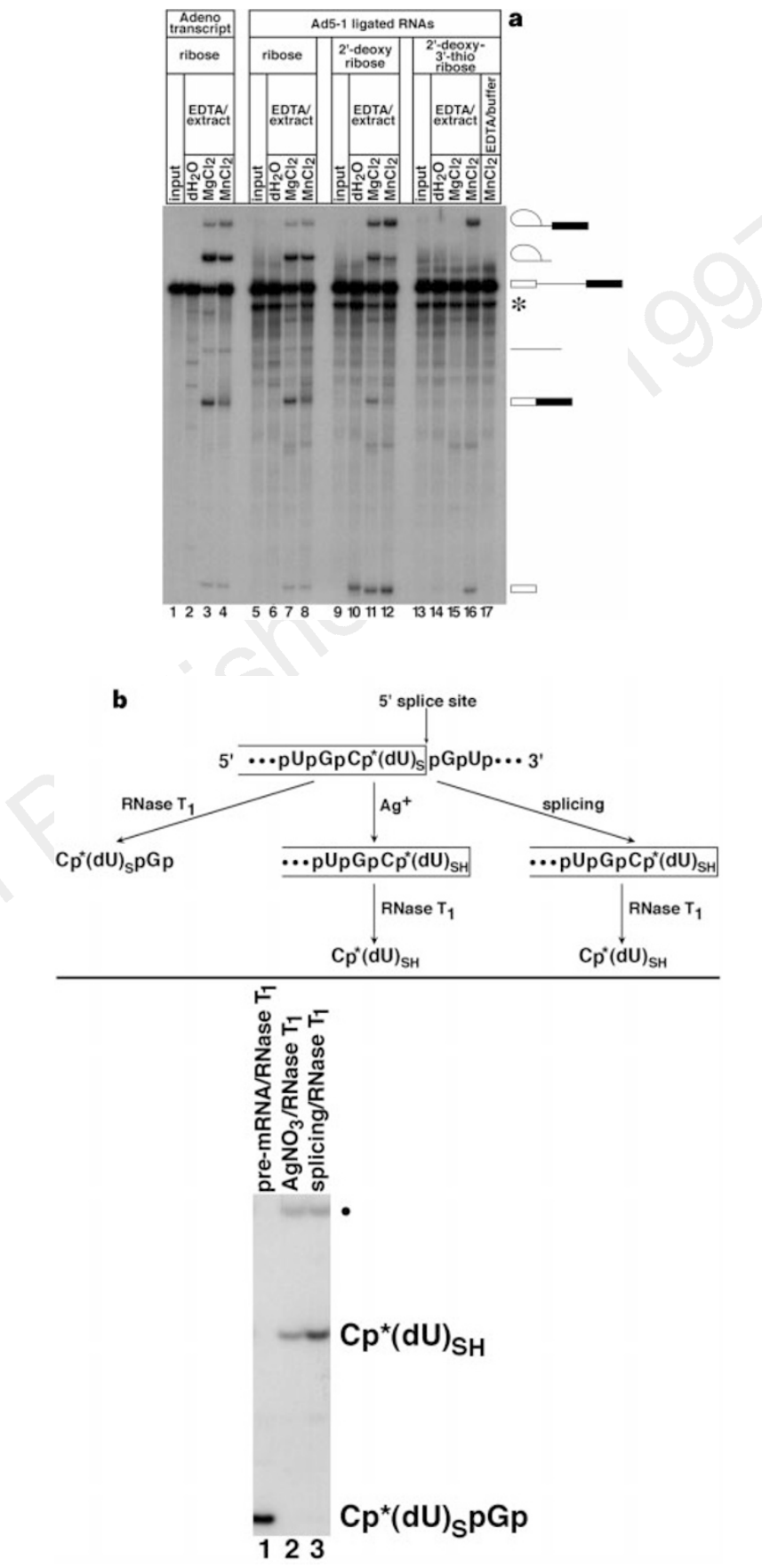

Figure 2 A $3^{\prime}$-thio substitution at the $5^{\prime}$ splice site results in a metal specificity switch. a, HeLa nuclear extract was used for in vitro splicing reactions with adenovirus transcript (lanes 1-4), Ad5-1R (lanes 5-8), Ad5-1D (lanes 9-12), or Ad5-1S (lanes 13-17) pre-mRNAs. Lanes 1, 5, 9 and 13 are unspliced RNAs. Splicing reactions contained no exogenous divalent metal ions (lanes 2, 6, 10 and 14), $1.5 \mathrm{mM} \mathrm{MgCl}_{2}$ (lanes 3, 7,11 and 15), or $1.5 \mathrm{mM} \mathrm{MnCl}_{2}$ (lanes 4, 8, 12,16 and 17). In lane 17, buffer replaced nuclear extract. Splicing precursor, intermediates and products are shown schematically on the right; the asterisk denotes residual unligated 3 ' half RNA. With the Ad5-1D substrate, a product of slightly decreased mobility relative to exon 1 intermediate is reproducibly observed when the reactions lack exogenous divalent metal ions (lane 10). This product is not accompanied by the appearance of any lariat species, and is therefore unlikely to be related to splicing. b. The spliceosome accurately cleaves the sulphurphosphorus bond of Ad5-1S pre-mRNA in the presence of $\mathrm{Mn}^{2+}$. The strategy for mapping the $5^{\prime}$ splice site is shown at the top (also see text). Standards are identified on the right. The upper band in lanes 2 and 3 (indicated by a dot) may be identical to the $C p^{*}(d U)_{S H}$ dinucleotide, except that the sulphydryl group became oxidized during work-up. 
$3^{\prime}$-S-phosphorothiolate linkage can be specifically hydrolysed in the presence of dilute aqueous $\mathrm{AgNO}_{3}$; normal phosphodiester linkages are unaffected ${ }^{15,16} \cdot \mathrm{Ag}^{+}$treatment combined with $\mathrm{RNase} \mathrm{T}_{1}$ digestion produces the dinucleotide $5^{\prime}-\mathrm{Cp}^{\star}(\mathrm{dU})_{\mathrm{SH}^{-}} 3^{\prime}$, containing a free $3^{\prime}$ thiol (Fig. 2b, lane 2). RNase $\mathrm{T}_{1}$ digestion of the purified exon 1 intermediate from an $\mathrm{Ad} 5-1 \mathrm{~S} / \mathrm{Mn}^{2+}$ splicing reaction yielded the identical $5^{\prime}-\mathrm{Cp}^{\star}(\mathrm{dU})_{\mathrm{SH}^{-}} 3^{\prime}$ dinucleotide (Fig. 2b, lane 3); iodoacetamide, which reacts specifically with sulphydryls, quantitatively derivatized the dinucleotide to the more slowly migrating acetamide thioether ${ }^{16}$, consistent with the presence of the $3^{\prime}$-thiol (data not shown). These results confirm that the spliceosome cleaved the sulphur-phosphorus bond of the Ad5-1S substrate.

The inhibition of Ad5-1S splicing in $\mathrm{MgCl}_{2}$ could arise from a failure of the spliceosomal complex to assemble, rather than from a defect in the chemical step of the splicing reaction. We monitored the assembly of splicing complexes on the Ad5-1S and Ad5-1D substrates in the presence of $\mathrm{MgCl}_{2}$ by electrophoresis in nondenaturing gels ${ }^{17}$ (Fig. 3). Assembly of the prespliceosomal A complex, the spliceosomal B complex and the catalytically activated C complex was equally efficient with Ad5-1S and Ad5-1D (Fig. 3), even though Ad5-1S did not give rise to splicing intermediates or products in the presence of $\mathrm{MgCl}_{2}$ (Fig. 2a, lane 15). Thus the $3^{\prime}$ thio modification does not interfere with spliceosome assembly in the presence of $\mathrm{MgCl}_{2}$, but rather blocks some subsequent step, such as catalysis of phosphotransesterification within the assembled spliceosomal active site.

If the inhibition of Ad5-1S splicing in $\mathrm{MgCl}_{2}$ is due to a specific defect in the chemical step of the reaction, rather than being a general consequence of having the modified linkage in the vicinity of the $5^{\prime}$ splice site, then substitution of a nearby nucleoside with $2^{\prime}$ deoxy- $3^{\prime}$-thiouridine should have no effect on splicing activity. We synthesized pre-mRNAs containing uridine, $2^{\prime}$-deoxyuridine, or $2^{\prime}$ deoxy-3'-thiouridine two bases downstream of the splice site $(\mathrm{Ad} 5+2 \mathrm{R}, \mathrm{Ad} 5+2 \mathrm{D}$ and $\mathrm{Ad} 5+2 \mathrm{~S}$, respectively) in the highly conserved GU dinucleotide. All three ligated pre-mRNAs were

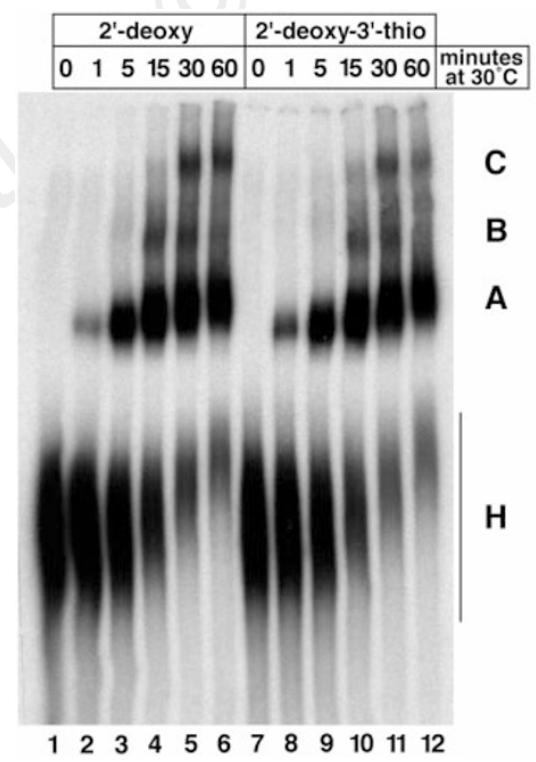

Figure 3 The 3 '-thio modification does not inhibit spliceosome assembly when $\mathrm{Mg}^{2+}$ is present as the sole divalent metal ion. The Ad5-1D (lanes 1-6) or Ad5-1S (lanes 7-12) pre-mRNAs were spliced in vitro for the times indicated at the top of each lane, and splicing complexes were fractionated by electrophoresis on a non-denaturing $4 \%$ polyacrylamide gel ${ }^{17}$. The mobilities and kinetics of nonspecific $\mathrm{H}$ complex, pre-spliceosomal A complex, spliceosomal B complex and catalytically activated spliceosomal $\mathrm{C}$ complex (indicated on the right) conform to previously observed patterns. ${ }^{17}$ spliced as efficiently as the transcribed control pre-mRNA (data not shown), indicating that the inhibition of splicing in $\mathrm{MgCl}_{2}$ is specific to $3^{\prime}$-thio substitution at the $5^{\prime}$ splice junction itself. Efficient splicing of the Ad5 $+2 \mathrm{D}$ and $\mathrm{Ad} 5+2 \mathrm{~S}$ substrates also demonstrates that spliceosome assembly and splicing do not require the $2^{\prime}$-hydroxyl group of the $U$ residue within the nearly invariant GU dinucleotide, as inferred from oligonucleotide trans-splicing reactions ${ }^{18}$.

Given that $\mathrm{Mn}^{2+}$ coordinates sulphur much more effectively than does $\mathrm{Mg}^{2+}$ (refs 5-8), the strong preference for $\mathrm{Mn}^{2+}$ by the $5^{\prime}$ splice-site-substituted precursor implies that the sulphur atom interacts with $\mathrm{Mn}^{2+}$ during the catalytic process. We infer that there could be an analogous metal ion-oxygen interaction during splicing of the unmodified precursor (Fig. 4). Before reaction, this interaction is expected to be weak or even repulsive ${ }^{19}$. As the scissile phosphodiester bond breaks, the 3'-oxygen develops negative charge in the transition state and the interaction with the metal ion should strengthen. An appropriately positioned metal ion in the spliceosomal active site could therefore selectively stabilize the transition state relative to the ground state, enhancing the reaction rate. Although it is not known whether protein or RNA mediates the phosphotransesterification reactions in the spliceosome, we have shown that the first step of pre-mRNA splicing occurs by a strategy that is amenable to catalysis by $\mathrm{RNA}^{3}$.

$2^{\prime}$-Deoxy-3'-thiouridine could not be used as a probe for metal ion catalysis at the $3^{\prime}$ splice site for two reasons: an absence of the $2^{\prime}-$ hydroxyl group at the $3^{\prime}$ splice site causes a $95 \%$ decrease in the efficiency of exon ligation ${ }^{9}$; and mutation of the highly conserved guanosine at the intron terminus to uridine abolishes pre-mRNA splicing ${ }^{20}$. However, site-specific substitution of inosine for guanosine at the $3^{\prime}$ splice site does not impair the rate or accuracy of premRNA splicing in vitro ${ }^{21}$. Because an RNA dinucleotide containing $3^{\prime}$-thioinosine had already been characterized ${ }^{16}$, we developed a synthetic route to the phosphoramidite of $3^{\prime}$-thioinosine rather than $3^{\prime}$-thioguanosine (S.S. and J.A.P., manuscript in preparation).

We synthesized an adenovirus-derived splicing substrate (Ad3$1 \mathrm{~S})$ containing a single $3^{\prime}$-thioinosine at the $3^{\prime}$ splice site (Fig. 1b), in which sulphur replaces the $3^{\prime}$-oxygen leaving group in the second step of splicing. We also prepared the standard transcribed adenovirus substrate ${ }^{10}$, as well as ligated control substrates containing a

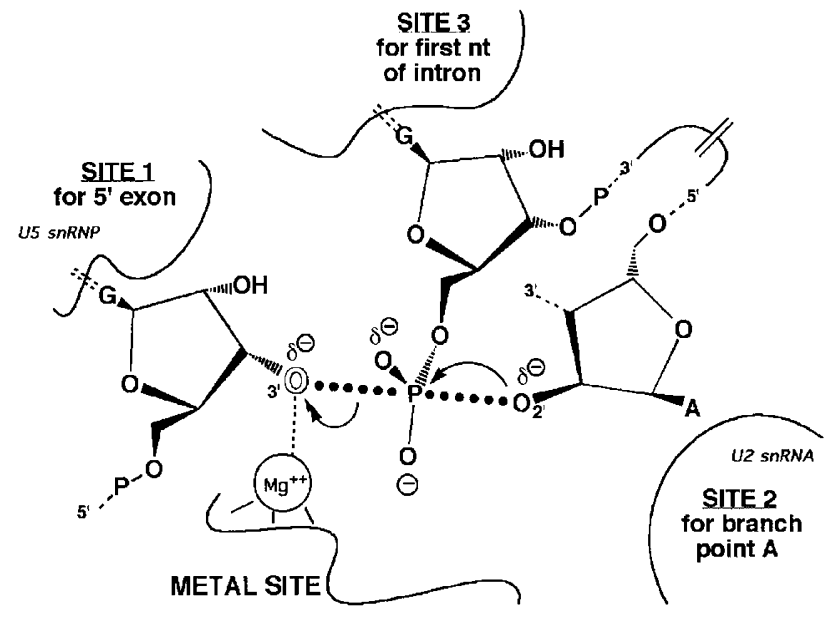

Figure 4 A catalytic metal ion is present in the spliceosomal active site for the first step of pre-mRNA splicing. The three nucleotides that participate directly in the first step of pre-mRNA splicing-the last base of exon 1, the branch point adenosine, and the first base of the intron-are shown bound to sites 1,2 and 3 within the spliceosomal active site $^{2}$. A catalytic magnesium ion is inferred from this work to bind in the spliceosomal active site and directly coordinate the $3^{\prime}$ oxyanion leaving group in the proposed transition state. Adapted from ref. 2. 
guanosine $(\mathrm{Ad} 3-1 \mathrm{G})$ or inosine $(\mathrm{Ad} 3-1 \mathrm{I})$ at the $3^{\prime}$ splice site, and tested all four substrates for in vitro splicing in EDTA-pretreated HeLa nuclear extract (Fig. 5). No splicing occurred in the absence of exogenous divalent metal ions (Fig. 5, lanes 2, 6, 10 and 14). As expected, efficient splicing occurred with the control adeno transcript and the Ad3-1G and Ad3-1I ligated substrates in the presence of either $1.5 \mathrm{mM} \mathrm{MgCl}_{2}$ (Fig. 5, lanes 3, 7 and 11) or $1.5 \mathrm{mM} \mathrm{MnCl}_{2}$ (Fig. 5, lanes 4, 8 and 12). In contrast to the results obtained at the $5^{\prime}$ splice site, however, both steps of splicing occurred efficiently with the Ad3-1S 3'-thio substituted pre-mRNA in the presence of either of the divalent metal ions $\mathrm{Mg}^{2+}$ or $\mathrm{Mn}^{2+}$ (Fig. 5, lanes 15 and 16). This result was obtained several times using different nuclear extracts and different metal ion preparations (data not shown). Treatment of Ad3-1S pre-mRNA with $\mathrm{AgNO}_{3}$ (ref. 15) gave nearly quantitative conversion to the expected hydrolysis products (data not shown), confirming the presence of the $3^{\prime}-S$-phosphorothiolate linkage in the pre-mRNA. Sequencing of the Ad3-1 spliced products from splicing reactions carried out in either $\mathrm{Mg}^{2+}$ or $\mathrm{Mn}^{2+}$ showed that the correct $3^{\prime}$ splice site was used in both cases (data not shown). The possibility that added $\mathrm{Mg}^{2+}$ displaces trace proteinbound thiophilic metal ions, freeing them to support splicing of the 3 '-thio-substituted pre-mRNA, is highly unlikely; our splicing reactions contained $0.8 \mathrm{mM}$ EDTA, and the EDTA stability constants of most thiophilic divalent metal ions are at least five orders of magnitude greater than that of $\mathrm{Mg}^{2+}$ (ref. 22). Hence, almost all released thiophilic metal ions would have been chelated by EDTA. Furthermore, such a displacement effect might have resulted in splicing of the $5^{\prime}$-splice-site-substituted pre-mRNA in $\mathrm{Mg}^{2+}$, which we did not observe (Fig. 2a, lane 15). We conclude that the sulphur leaving group in the exon ligation reaction does not require the presence of a metal ion to which it can coordinate effectively.

A switch in metal specificity could be masked because the chemical step of exon ligation may not be rate-limiting; however, it seems likely that disruption of an important metal ion interaction would have reduced the efficiency of splicing. For example, in the case of the Klenow fragment, there is structural evidence for a metal

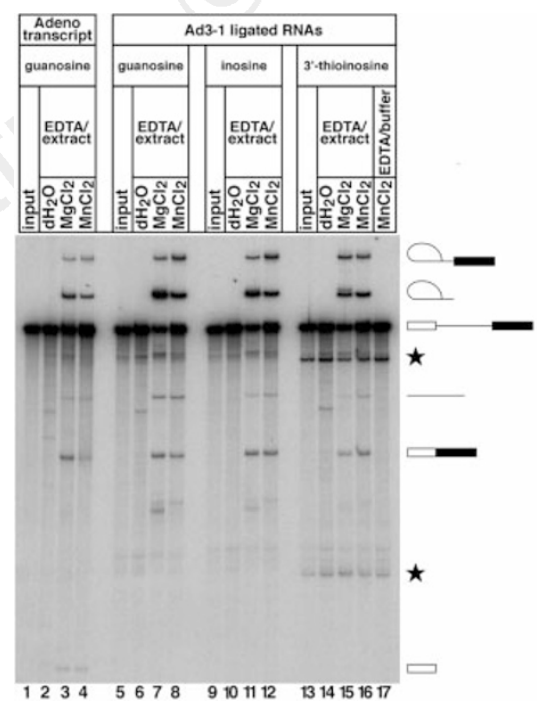

Figure $5 \mathrm{Mg}^{2+}$ supports in vitro splicing of a pre-mRNA with a $3^{\prime}$-thio substitution at the $3^{\prime}$ splice site. In vitro splicing reactions were carried out with adenovirus transcript ${ }^{10}$ (lanes 1-4) and Ad3-1G (lanes 5-8), Ad3-1I (lanes 9-12), and Ad3-1S (lanes 13-17) ligated RNAs as for Fig. 2a. Splicing precursor, intermediates and products are shown schematically on the right. Stars indicate background cleavage products (RNA containing an inosine 3'-S-phosphorothiolate linkage cleaves $\sim 2,000$-fold faster than unmodified phosphate-linked RNA $\left.{ }^{16}\right)$. For the ligated pre-mRNAs, the exon 1 intermediate contains no radiolabel and is therefore not visible. ion-leaving group interaction at the $3^{\prime}-5^{\prime}$ exonuclease active $\operatorname{sit}^{23}$, and thio substitution of the leaving group decreases $k_{\text {cat }} / K_{\mathrm{M}}$ by $\sim 50,000$-fold in the presence of $\mathrm{Mg}^{2+}$ (J. F. Curley, C. M. Joyce, and J.A.P., manuscript submitted). Alternatively, there may be no interaction between a metal ion and the leaving group in the second chemical step of splicing. The spliceosome may stabilize the leaving group by some means other than that observed in the first reaction step, such as general acid catalysis and/or hydrogen-bond donation: the source of this proton or hydrogen-bond donor could be a metalbound water molecule, an RNA residue with a locally perturbed $\mathrm{p} K_{\mathrm{a}}$, or a spliceosomal protein side chain. The first and second reaction steps probably occur at distinct active sites: for example, blockage of both reaction steps by the same phosphorothioate diastereomer argues that they are not simply forward and reverse reactions at a single active site ${ }^{24}$, where the same metal ion stabilizes the leaving group in the first step and activates the nucleophile in the second step ${ }^{2}$. Our observation that $3^{\prime}$-thio substitution blocks $\mathrm{Mg}^{2+}$-mediated splicing at the $5^{\prime}$ splice site but not the $3^{\prime}$ splice site argues against the alternative possibility that the two steps proceed as parallel reactions in a single active site, in which the same metal ion stabilizes the leaving group in both steps.

\section{Methods}

Pre-mRNA substrates. We synthesized $5^{\prime}-O$-monomethoxytrityl-2'-deoxy- $3^{\prime}$ thiouridine $3^{\prime}-S$-phosphoramidite as described ${ }^{3}$; synthesis of the $5^{\prime}$-O-dimethoxytrityl-2'-O-t-butyldimethylsilyl-3' -thioinosine- $3^{\prime}-S$-phosphoramidite will be reported elsewhere. All dinucleotides and oligonucleotides were synthesized on a Millipore solid-phase DNA/RNA synthesizer and deprotected and purified using standard procedures, except that 2 '-deoxy-3' -thiouridine and 3 '-thioinosine were incorporated as described ${ }^{4}$. We synthesized the following dinucleotides and oligonucleotides: 5' $-(\mathrm{dU})_{\mathrm{s}} \mathrm{pG}-3^{\prime}, 5^{\prime}$-(dU)pG-3', Ad5-1R/21 (5'-UGUGAGUACUCCCUCUCAAAA-3'), Ad5-1D/21 (5'-(dU)GUGAG UACUCCCUCUCAAAA-3'), Ad5-1S/21 (5'-(dU) ${ }_{s}$ GUGAGUACUCCCUCU CAAAA- $\left.3^{\prime}\right)$, Ad5-2-10p (5'-pCAGCUGUUGC-3'), Ad3-1G (5'-AGCUCG CGGUU-3'), Ad3-1I (5'-AICUCGCGGUU-3'), and Ad3-1S ( $5^{\prime}-\mathrm{AI}_{\mathrm{s}} \mathrm{CUC}$ GCGGUU-3') $\left((\mathrm{dU})\right.$ is $2^{\prime}$-deoxyuridine, $(\mathrm{dU})_{\mathrm{s}}$ is $2^{\prime}$-deoxy- $3^{\prime}$-thiouridine, $\mathrm{p}$ is phosphate, $\mathrm{I}$ is inosine, and $\mathrm{I}_{\mathrm{s}}$ is $3^{\prime}$-thioinosine).

For the experiments shown in Figs 2a and 3, we synthesized the Ad5-1 substrates as described ${ }^{25}$, except that the dinucleotides UpG (Sigma), (dU)pG, or $(\mathrm{dU})_{\mathrm{s}} \mathrm{pG}$ were used to initiate transcription of the $3^{\prime}$ half RNA, and the $3^{\prime}$ half RNA was labelled internally with $\left[\alpha-{ }^{32} \mathrm{P}\right] \mathrm{UTP}$. We synthesized the Ad $5+2$ substrates as described ${ }^{25}$, using the dinucleotides $U p G,(d U) p G$ or $(d U){ }_{s} p G$ to initiate transcription of the $3^{\prime}$ half RNA. For the experiment shown in Fig. 2b, we synthesized the Ad5-1 substrates with a single ${ }^{32} \mathrm{P}$-phosphate adjacent to the modified nucleotide. The Ad5-1R/21, Ad5-1D/21 and Ad5-1S/21 oligonucleotides were $5{ }^{\prime}-{ }^{32} \mathrm{P}$-phosphorylated and ligated ${ }^{26}$ to the Ad5-2-10p oligonucleotide to generate the fragments Ad5-1R/30, Ad5-1D/30 and Ad5-1S/30, respectively. We then ligated these fragments to Ad5-10 5' RNA (corresponding to the first 57 nucleotides of exon 1) and Ad5 $+213^{\prime}$ RNA (corresponding to the last 223 nucleotides of the intron and all 99 nucleotides of exon 2).

For synthesis of the Ad3-1 substrates, the Ad3-1G, Ad3-1I and Ad3-1S oligonucleotides were $5^{\prime}{ }^{32} \mathrm{P}$-phosphorylated and ligated ${ }^{26}$ to the Ad3-3 5' RNA (corresponding to exon 1 and the first 241 nucleotides of the intron) and the Ad3 + $103^{\prime}$ RNA (corresponding to nucleotides 10-99 of exon 2). Before the ligation reactions, we $3^{\prime}$-end-labelled the Ad $3+103^{\prime}$ RNA with $\left[\alpha-{ }^{32} \mathrm{P}\right]$ cordycepin triphosphate using yeast poly(A) polymerase (US Biochemicals).

Nuclear extracts and in vitro splicing reactions. HeLa cells were purchased from the National Cell Culture Center (Minnesota), and nuclear extract prepared as described ${ }^{27}$, except that dialysis buffer contained $42 \mathrm{mM}$ $\left(\mathrm{NH}_{4}\right)_{2} \mathrm{SO}_{4}$ instead of $\mathrm{KCl}$. For in vitro splicing, nuclear extract (already containing $0.2 \mathrm{mM}$ EDTA) was supplemented with an additional $2.5 \mathrm{mM}$ $\mathrm{EDTA}^{28}$, and incubated on ice for $30 \mathrm{~min}$. Splicing reactions $(10 \mu \mathrm{l})$ included $30 \%$ nuclear extract (final EDTA concentration $0.8 \mathrm{mM}$ ), $0.5 \mathrm{mM}$ ATP, $0.1 \mathrm{mM}$

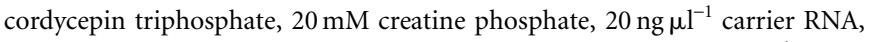
trace quantities of radiolabelled splicing substrate, and 1-2 units $\mu \mathrm{l}^{-1} \mathrm{RNA}$ guard RNase inhibitor (Promega). We also included water, $\mathrm{MgCl}_{2}$ or $\mathrm{MnCl}_{2}$, as described in the text and figure legends; metal ion chlorides (Aldrich) were $>99.99 \%$ 
pure. Splicing reactions were for $1-2 \mathrm{~h}$ at $30^{\circ} \mathrm{C}$. Extracted and precipitated RNAs were fractionated on a denaturing $8 \%$ polyacrylamide gel; the gel and electrophoresis buffer $(1 \times \mathrm{TBE})$ contained $10 \mathrm{mM}$ dithiothreitol (DTT) and gels were pre-run for at least $6 \mathrm{~h}$.

Splice-site mapping. For 5' -splice-site mapping, we included the Ad5-1S premRNA in splicing reactions as described and gel-purified the $5^{\prime}$ exon intermediate. To generate a standard, the Ad5-1S/30 fragment was treated with $\mathrm{AgNO}_{3}$ (ref. 15), and the 10-nucleotide labelled product of silver cleavage ( $5^{\prime}$-pCAGCUGUUGC $(\mathrm{dU})_{\mathrm{SH}^{-}} 3^{\prime}$ ) was purified in a $20 \%$ polyacrylamide denaturing gel containing $10 \mathrm{mM}$ DTT. Following elution, we desalted the oligonucleotide in a Sep-Pac $\mathrm{C}_{18}$ cartridge (Waters) and dried it in vacuo. The purified 5' exon intermediate, the $\mathrm{Ag}^{+}$-cleaved fragment, and the Ad5-1 premRNA were digested with RNase $\mathrm{T}_{1}$ and fractionated in a $20 \%$ polyacrylamide denaturing gel containing $10 \mathrm{mM}$ DTT. RNase $\mathrm{T}_{1}$ digestions ${ }^{9}$ contained $10 \mathrm{mM}$ DTT.

For 3 '-splice-site mapping, extracted and precipitated RNAs from $100-\mu \mathrm{l}$ splicing reactions (Fig. 3b, lanes 15 and 16) were reverse transcribed using a DNA primer (Ad.33) complementary to the 3 '-terminal 21 nucleotides of the Ad3-1S substrate. We used the products of these reactions as PCR templates, with Ad.33 primer and another oligonucleotide (Ad.55) corresponding to the 5 '-terminal 20 nucleotides of the Ad3-1S substrate, and sequenced the PCR products derived from ligated exons.

Received 25 February; accepted 21 May 1997

1. Krämer, A. in Pre-mRNA Processing (ed. Lamond, A.) 35-64 (Landes, Austin, 1995)

2. Steitz, T. A. \& Steitz, J. A. A general two-metal-ion mechanism for catalytic RNA. Proc. Natl Acad. Sci. USA 90, 6498-6502 (1993).

3. Piccirilli, J. A., Vyle, J. S., Caruthers, M. H. \& Cech, T. R. Metal ion catalysis in the Tetrahymena ribozyme reaction. Nature 361, 85-88 (1993).

4. Cosstick, R. \& Vyle, J. S. Synthesis and properties of dithymidine phosphate analogues containing 3'thiothymidine. Nucleic Acids Res. 18, 829-835 (1990).

5. Jaffe, E. K. \& Cohn, M. Divalent cation-dependent stereospecificity of adenosine $5^{\prime}-O$-(2-thiotriphosphate) in the hexokinase and pyruvate kinase reactions: The absolute stereochemistry of the diastereomers of adenosine 5'-O-(2-thiotriphosphate). J. Biol. Chem. 253, 4823-4825 (1978).

6. Jaffe, E. K. \& Cohn, M. Diastereomers of the nucleoside phosphorothioates as probes of the structure of the metal nucleotide substrates and of the nucleotide binding site of yeast hexokinase. J. Biol. Chem. 254, 10839-10845 (1979)

7. Pecoraro, V. L., Hermes, J. D. \& Cleland, W. W. Stability constants of $\mathrm{Mg}^{2+}$ and $\mathrm{Cd}^{2+}$ complexes of adenine nucleotides and thionucleotides and rate constants for formation and dissociation of MgATP and MgADP. Biochemistry 23, 5262-5271 (1984).

8. Sigel, R. K. O., Song, B. \& Sigel, H. Stabilities and structures of metal ion complexes of adenosine $5^{\prime}-O$ thiomonophosphate $\left(\mathrm{AMPS}^{2-}\right)$ in comparison with those of its parent nucleotide $\left(\mathrm{AMP}^{2-}\right)$ in aqueous solution. J. Am. Chem. Soc. 119, 744-755 (1997).

9. Moore, M. J. \& Sharp, P. A. Site-specific modification of pre-mRNA: The 2'-hydroxyl groups at the splice sites. Science 256, 992-997 (1992).

10. Solnick, D. Trans splicing of mRNA precursors. Cell 42, 157-164 (1985).

11. Pearson, R. G. Acids and bases. Science 151, 172-177 (1966).

12. Dantzmann, C. L. \& Kiessling, L. L. Reactivity of a $2^{\prime}$-thio nucleotide analog. J. Am. Chem. Soc. 118 $11715-11719$ (1996)

13. Burgin, A. B., Huizenga, B. N. \& Nash, H. A. A novel suicide substrate for DNA topoisomerases and site-specific recombinases. Nucleic Acids Res. 23, 2973-2979 (1995).

14. Seiwert, S. D. \& Steitz, J. A. Uncoupling two functions of the U1 small nuclear ribonucleoprotein particle during in vitro splicing. Mol. Cell. Biol. 13, 3135-3145 (1993).

15. Vyle, J. S., Connolly, B. A., Kemp, D. \& Cosstick, R. Sequence- and strand-specific cleavage in oligodeoxyribonucleotides and DNA containing 3'-thiothymidine. Biochemsitry 31, 3012-3018 (1992).

16. Weinstein, L. B., Earnshaw, D. J., Cosstick, R. \& Cech, T. R. Synthesis and characterization of an RNA dinucleotide containing a 3'-S-phosphorothiolate linkage. J. Am. Chem. Soc. 118, 10341-10350 (1996).

17. Konarska, M. M. \& Sharp, P. A. Electrophoretic separation of complexes involved in the splicing of precursors to mRNAs. Cell 46, 845-855 (1986).

18. Reyes, J. L., Kois, P., Konforti, B. B. \& Konarska, M. M. The canonical GU dinucleotide at the 5 ' splice site is recognized by p220 of the U5 snRNP within the spliceosome. RNA 2, 213-225 (1996).

19. Narlikar, G. J., Gopalakrishnan, V., McConnell, T. S., Usman, N. \& Herschlag, D. Use of binding energy by an RNA enzyme for catalysis by positioning and substrate destabilization. Proc. Natl Acad. Sci. USA 92, 3668-3672 (1995).

20. Aebi, M., Hornig, H., Padgett, R. A., Reiser, J. \& Weissmann, C. Sequence requirements for splicing of higher eukaryotic nuclear pre-mRNA. Cell 47, 555-565 (1986).

21. Tarn, W.-Y. Site-specific substitution of inosine at the terminal positions of a pre-mRNA intron Implications for the configuration of the terminal base interaction. Biochimie (in the press).

22. Anderegg, G. in Comprehensive Coordination Chemistry: The Synthesis, Reactions, Properties and Applications of Coordination Compounds (eds Wilkinson, G., Gillard, R. D. \& McCleverty, J. A.) 777792 (Pergamon, Oxford, 1987)

23. Freemont, P. S., Friedman, J. M., Beese, L. S., Sanderson, M. R. \& Steitz, T. A. Cocrystal structure of an editing complex of Klenow fragment with DNA. Proc. Natl Acad. Sci. USA 85, 8924-8928 (1988).

24. Moore, M. J. \& Sharp, P. A. Evidence for two active sites in the spliceosome provided by stereochemistry of pre-mRNA splicing. Nature 365, 364-368 (1993)

25. Sontheimer, E. J. \& Steitz, J. A. The U5 and U6 small nuclear RNAs as active site components of the spliceosome. Science 262, 1989-1996 (1993).

26. Query, C. C., Moore, M. J. \& Sharp, P. A. Branch nucleophile selection in pre-mRNA splicing: evidence for the bulged duplex model. Genes Dev. 8, 587-597 (1994).

27. Dignam, J. D., Lebovitz, R. M. \& Roeder, R. G. Accurate transcription initiation by RNA polymerase II in a soluble extract from isolated mammalian nuclei. Nucleic Acids Res. 11, 1475-1489 (1983).
28. Abmayr, S. M., Reed, R. \& Maniatis, T. Identification of a functional mammalian spliceosome containing unspliced pre-mRNA. Proc. Natl Acad. Sci. USA 85, 7216-7220 (1988).

Acknowledgements. We thank M. Hamm and L. Munishkina for oligonucleotide synthesis, W.-Y. Tarn for communicating unpublished results, members of our laboratory for advice and discussions, and J. Curley, M. Hamm and A. Yoshida for comments on the manuscript. E.J.S. was supported in part by a postdoctoral fellowship from the Jane Coffin Childs Memorial Fund for Medical Research. E.J.S. and S.S. are research associates and J.A.P. is an assistant investigator of the Howard Hughes Medical Institute.

Correspondence and requests for materials should be addressed to J.A.P. (e-mail: jpicciri@midway. uchicago.edu).

\section{A second catalytic metal ion in a group I ribozyme}

\section{Lara B. Weinstein*, B. C. N. M. Jones $\dagger$, Richard Cosstick $\dagger$ \& Thomas R. Cech*}

${ }^{*}$ Howard Hughes Medical Institute, Department of Chemistry and Biochemistry, University of Colorado, Boulder, Colorado 80309-0215, USA

$\dagger$ Robert Robinson Laboratory, Department of Chemistry, University of Liverpool, Liverpool L69 3BX, UK

Although only a subset of protein enzymes depend on the presence of a metal ion for their catalytic function, all naturally occurring RNA enzymes require metal ions to stabilize their structure and for catalytic competence ${ }^{1}$. In the self-splicing group I intron from Tetrahymena thermophila ${ }^{2}$, several divalent metals can serve structural roles, but only $\mathrm{Mg}^{2+}$ and $\mathrm{Mn}^{2+}$ promote splice-site cleavage and exon ligation ${ }^{3,4}$. A study of a ribozyme reaction analogous to $5^{\prime}$-splice-site cleavage by guanosine uncovered the first metal ion with a definitive role in catalysis. Substitution of the $3^{\prime}$-oxygen of the leaving group with sulphur resulted in a metal-specificity switch, indicating an interaction between the leaving group and the metal ion ${ }^{5}$. Here we use $3^{\prime}$ (thioinosylyl)-( $\left(3^{\prime} \rightarrow 5^{\prime}\right)$-uridine $e^{6}$, IspU, as a substrate in a reaction that emulates exon ligation. Activity requires the addition of a thiophilic metal ion $\left(\mathrm{Cd}^{2+}\right.$ or $\left.\mathrm{Mn}^{2+}\right)$, providing evidence for stabilization of the leaving group by a metal ion in that step of splicing. Based on the principle of microscopic reversibility, this metal ion activates the nucleophilic $3^{\prime}$-hydroxyl of guanosine in the first step of splicing, supporting the model of a two-metal-ion active site ${ }^{7}$.

The self-splicing reaction performed by the Tetrahymena intron consists of two consecutive phosphotransesterification reactions. The mechanism of the first step, $5^{\prime}$-splice-site cleavage, has been studied using a truncated form of the intron (L-21 ScaI) in the forward reaction $(\mathrm{G}+\mathrm{CCCUCUpA} \rightarrow \mathrm{GpA}+\mathrm{CCCUCU}$, where only the reactive phosphate is shown explicitly) (Fig. 1a) ${ }^{2,8}$. The second step of splicing, exon ligation, is chemically the reverse of the first step ${ }^{9}$ and is thought to occur in the same active site ${ }^{10,11}$. This step is mimicked by the reverse of the ribozyme reaction $(\mathrm{GpN}+\mathrm{CCCUCU} \rightarrow \mathrm{G}+\mathrm{CCCUCUpN}$, where $\mathrm{N}$ is $\mathrm{A}, \mathrm{C}$ or $\mathrm{U})$ (Fig. 1a $)^{12-14}$. Kinetic studies of this reverse reaction have used dinucleotides with guanosine at the $5^{\prime}$-position. However, inosine will substitute for guanosine in both splicing and the enzymatic forward reaction ${ }^{15,16}$. For ease in chemical synthesis, we chose IspU, an inosine-containing dinucleotide with a $3^{\prime}$-S-phosphorothiolate linkage ${ }^{6}$, to prospect for a metal ion interacting with the leaving group in the reverse reaction (Fig. 1b).

Under conditions previously shown to support the reverse reaction efficiently, namely $\mathrm{pH} 7.0$ and high $\mathrm{MgCl}_{2}$ concentration $(110 \mathrm{mM})^{13}$, only the unmodified dinucleotide, IpU, was a substrate for transesterification (Fig. 2). Addition of $\mathrm{Mn}^{2+}$ (1-100 mM) resulted in progressively higher rates of transesterification of IspU (Fig. 2). To find conditions under which the observed rate constant $\left(k_{\text {obs }}\right)$ reflects the chemical step, a $\mathrm{pH}$ profile was determined for the 